\title{
Profil dan Kinerja Usaha Olahan Perikanan di Kelurahan Sarijaya Kecamatan Sanga Sanga Kabupaten Kutai Kartanegara
}

\author{
Gusti Haqiqiansyah $^{1^{*}}$ dan Eko Sugiharto ${ }^{2}$ \\ 1,2 Program Studi Sosial Ekonomi Perikanan \\ Fakultas Perikanan dan IImu Kelautan Unmul \\ Jalan Gunung Tabur Kampus Unmul Gunung Kelua Samarinda 75119 \\ ${ }^{1}$ Email: gusti.haqiqiansyah@fpik.unmul.ac.id \\ 2 Email: eko.sugiharto@fpik.unmul.ac.id \\ *Penulis korespondensi: gusti.haqiqiansyah@fpik.unmul.ac.id
}

\begin{abstract}
Fishery product processing business was an effort to increase and add value to fishery products. Activities that involve the community, especially womens who have the potential to be empowered. Fishery product processing activities, especially amplang processing in Sari Jaya Village, Sanga Sanga District, has been developing for a long time. Research aimed was to determine the business profile and business performance financially and to determine the breakeven point of production. The research was conducted using survey methods and interviews with business actors. The sample was taken by using the census method and the data were analyzed descriptively and financially. The research results showed that the business profile was household scale, simple technology, family labour and it has a business license (P-IRT). Financial analysis results showed that the balance value of revenue and costs was 2.19, it means by financially this business is profitable and prospects to be developed. Analysis results of break-even point production were $118 \mathrm{~kg}$ per month, while an average production actual is $258 \mathrm{~kg}$ per month. While the actual average production was $258 \mathrm{~kg}$ per month. The breakeven point price is at level of Rp. 45,697 per kg. As for advice, intensive assistance required by technical agencies, especially field extension workers so that they can improve the quality of production and partnership programs to expand market segmentation.
\end{abstract}

Keywords: Break Even Point, Business Performance, Fishery Processing, Profile, Sari Jaya Village

\begin{abstract}
ABSTRAK
Usaha pengolahan hasil perikanan merupakan suatu upaya untuk meningkatkan dan menambah nilai tambah terhadap produk hasil perikanan. Kegiatan yang banyak melibatkan masyarakat terutama ibu-ibu yang potensial untuk diberdayakan. Kegiatan pengolahan hasil perikanan, terutama olahan amplang di Kecamatan Sanga Sanga, khususnya Kelurahan Sari Jaya sudah cukup lama berkembang. Tujuan penelitian adalah untuk mengetahui profil usaha dan kinerja usaha secara finansial serta mengetahui titik impas produksi. Penelitian dilakukan dengan metode survei dan wawancara dengan pelaku usaha. Pengambilan sampel dengan metode sensus dan data dianalisis secara deskriptif dan finansial. Hasil penelitian, menunjukan bahwa profil usaha adalah skala rumah tangga, teknologi sederhana, tenaga kerja keluarga dan sudah memiliki izin usaha ( $P$ IRT). Hasil analisis finansial nahwa nilai imbangan penerimaan dan biaya sebesar 2,19 , berarti secara finansial usaha ini menguntungan dan prospek untuk dikembangkan. Hasil analisis titik impas produksi sebesar $118 \mathrm{~kg}$ per bulan, sedangkan produksi rata-rata aktual sebesar $258 \mathrm{~kg}$ per bulan. Titik impas harga berada pada tingkat $45.697 \mathrm{~kg}$. Adapun saran perlunya pendampingan yang intensif oleh instansi teknis terutama tenaga penyuluh lapangan sehingga dapat
\end{abstract}


meningkatkan kualitas produksi dan program kemitraan guna perluasan segmentasi pasar.

Kata kunci: Profil, Kelurahan Sari Jaya, Kinerja Usaha, Olahan Perikanan, Titik Impas

\section{Pendahuluan}

Produksi hasil perikanan Kabupaten Kutai Kartanegara sebesar 177.305 ton dengan jumlah konsumsi ikan sebesar 74,8 kg/kapita/tahun. Kecamatan Sanga-Sanga merupakan satu diantara kecamatan yang berada di wilayah pesisir, dengan potensi sumberdaya perikanan relatif kecil jika dibandingkan dengan kecamatan di wilayah pesisir lainnya. (Dinas Kelautan dan Perikanan Kabupaten Kutai Kartanegara, 2018). Upaya pengdiversifikasi produk olahan perikanan perlu dikembangkan. Hasil penelitian Nugroho (2015) menegaskan bahwa konsep kebijakan pengembangan ekonomi produktif usaha pengolahan hasil perikanan yang berkelanjutan, dengan metode pelatihan dan pendampingan keluarga nelayan dapat meningkatkan kesejahteraan masyarakat nelayan. Yudaswara et al., (2018) bahwa usaha pengolahan hasil perikanan berbahan baku ikan prospektif untuk dikembangan. Hal ini mengindikasikan bahwa pengdiversifikasian produk perikanan mampu memberi nilai tambah dan kontribusi terhadap pendapatan keluarga.

Kegiatan pemberdayaan masyarakat, terutama kelompok perempuan merupakan upaya untuk meningkatkan kemampuan dan potensi yang dimiliki oleh suatu masyarakat. Setyaningrum \& Hartanto (2020) menyatakan bahwa pemberdayaan perempuan melalui penguatan kelompok berdampak nyata dalam peningkatan kapasitas perempuan. sehingga mereka mampu mengaktualisasi jati diri, harkat dan martabatnya secara maksimal untuk bertahan dan mengembangkan diri secara mandiri. Hal ini dimaksudkan agar masyarakat dapat melepaskan diri perangkap kemiskinan dan keterbelakangan. Pemberdayaan ekonomi berarti menyangkut upaya peningkatan pendapatan dan tingkat kesejahteraan hidup yang bertumpu pada kekuatan ekonomi sendiri, sehingga masyarakat mampu memenuhi kebutuhan hidup secara mandiri. Hasil penelitian Haqiqiansyah \& Sugiharto (2018) bahwa tingkat kesadaran atau keinginan untuk berubah (power within) dari kelompok usaha pengolahan termasuk kategori tinggi. Hal ini merupakan peluang bagi pengembangan potensi masyarakat setempat. Sehingga peran aktif dan pembinaan bersinambungan perlu dilakukan.

Kegiatan usaha pengolahan amplang sudah cukup lama ditekuni oleh masyarakat, namun perjalanan banyak berfluktuasi karena pengaruh banyak faktor dan kendala yang sering dihadapi oleh pelaku usaha, Mengingat potensi dan peluang yang cukup besar untuk pengembangan usaha pengolahan hasil perikanan. Salah satu hasil laut yang banyak dimanfaatkan oleh masyarakat adalah ikan bandeng. Hasil tangkapan tersebut sebagian dipasarkan dalam bentuk segar, dan sebagian dilakukan proses pengolahan. Hasil produk telah dilakukan oleh masyarakat seperti usaha bandeng presto, usaha 
pengolahan kerupuk dan amplang. Usaha pengolahan hasil perikanan terutama ditujukan untuk memberikan nilai tambah terhadap produk perikanan dan diversifikasi usaha. Selain itu juga dapat menambah kesempatan kerja bagi masyarakat. Kegiatan ini perlu dilakukan untuk dapat menambah pendapatan masyarakat, dan sekaligus memanfaatkan potensi sumberdaya alam yang cukup besar. Potensi sumberdaya yang melimpah ini sebagian besar telah dimanfaatkan oleh masyarakat pesisir untuk melakukan usaha pengolahan.

Amplang merupakan makanan ringan yang terbuat dari ikan, biasanya berbentuk bulat dan berwarna putih. Amplang produk yang dikenali berasal dari Samarinda provinsi Kalimantan Timur. Makanan khas dari Samarinda ini mungkin menjadi oleh-oleh yang paling banyak dicari oleh pengunjung. Bentuk olahan ini bentuk beraneka ragam seperti bentuk kuku macan, panjang, tanggung, meriap dan bundar (Hadiwiyoto, 1993). Dengan semakin berkembangnya usaha ini, maka perlu dilakukan kajian untuk mengukur usaha ini bisa diketahui apakah secara ekonomi usaha tersebut sudah memberikan keuntungan dan layak untuk dilanjutkan. Adapun tujuan yang ingin dicapai adalah mengetahui profil usaha dan kinerja usaha dari aspek perbandingan biaya dan penerimaan, serta mengetahui titik impas produksi dan harga

\section{Metode Penelitian}

\section{Tempat dan Waktu Penelitian}

Penelitian ini dilaksanakan di Kecamatan Sanga-Sanga, Kabupaten Kutai Kartanegara. Waktu penelitian selama 3 bulan, dari bulan Oktober hingga Desember 2019

\section{Metode Pengambilan Data}

Metode penelitian yang digunakan dalam penelitian ini adalah metode survei. Yaitu melakukan pengamatan dan wawancara dengan responden. Adapun data yang diperlukan dalam penelitian ini adalah data primer dan data sekunder. Data primer merupakan data utama yang diperoleh secara langsung di lapangan, dengan wawancara mendalam dengan menggunakan kuisioner yang telah disusun seperti identitas responden, proses produksi, penggunaan factor produksi, komponen biaya usaha. Data sekunder diperoleh data statistik Kecamatan Sanga-Sanga, buku-buku dan literatur yang terkait dengan penelitian.

\section{Metode Pengambilan Sampel}

Populasi dalam penelitian ini adalah pengolah amplang di Kelurahan Sarijaya Kecamatan Sanga-Sanga dimana berdasarkan observasi lapangan jumlah pengolah yang ada sebanyak 4 orang, maka diambil secara sensus. 


\section{Metode Analisis Data}

Data yang diperoleh dari penelitian akan diolah dan dianalisis kemudian disajikan dalam bentuk tabel dan uraian. Jenis analisis yang akan digunakan dalam penelitian ini yaitu:

1. Analisis Imbangan Penerimaan dan Biaya (Revenue Cost Ratio)

Menurut Soekartawi (1990), untuk mengetahui apakah usaha tersebut menguntungkan atau tidak, dapat ditentukan dengan menggunakan analisis sebagai berikut:

$$
R / C=\frac{T R}{T C}
$$

Keterangan: R/C (Revenue Cost Ratio $)=$ Ratio Keuntungan Usaha

$$
\begin{array}{ll}
\mathrm{TR}(\text { Total Revenue }) & =\text { Penerimaan total }(\mathrm{Rp} / \mathrm{b} / \mathrm{n}) \\
\mathrm{TC}(\text { Total cost }) & =\text { Biaya total }(\mathrm{Rp} / \mathrm{bln})
\end{array}
$$

Dengan kriteria:

Jika Revenue Cost Ratio > 1, maka usaha menguntungkan serta layak untuk diteruskan. Jika Revenue Cost Ratio < 1, maka usaha tidak menguntungkan.

2. Analisis Titik Impas (Break Even Point)

Untuk mengetahui titik impas, maka rumus yang digunakan adalah (Effendi \& Oktariza, 2006):

$$
\begin{aligned}
& \text { BEP Produksi }=\frac{\text { Total Harga }}{\text { Harga Penjualan }} \\
& \text { BEP harga }=\frac{\text { Total Harga }}{\text { Produksi }}
\end{aligned}
$$

\begin{tabular}{|c|c|c|}
\hline Keterangan: & BEP produksi & $=$ Titik impas produksi \\
\hline & BEP harga & $=$ Titik impas harga \\
\hline
\end{tabular}




\section{Hasil dan Pembahasan}

\section{Keragaman Wilayah}

Kecamatan Sanga-Sanga memiliki luas sekitar 233,4 $\mathrm{km}^{2}$ dan wilayah terkecil di Kabupaten Kutai Kartanegara. Secara administratif berbatasan dengan beberapa wilayah sebagai berikut :

Sebelah Utara : Kecamatan Anggana

Sebelah Timur : Kecamatan Anggana

Sebelah Selatan : Kecamatan Muara Jawa

Sebelah Barat : Kota Samarinda

Wilayah tersebut berlklim tropis basah dengan rata-rata curah hujan 129 $\mathrm{mm} /$ bulan dan sebanyak 16 hari hujan/bulan. Curah hujan terendah terjadi pada bulan Februari sekitar $45 \mathrm{~mm} /$ bulan dan $8 \mathrm{hh} /$ bulan, sedangkan bulan Desember menjadi curah hujan tertinggi sekitar $211 \mathrm{~mm}$ dengan $26 \mathrm{hh}$. (Badan Pusat Statistik Kutai Kartanegara, 2018). Terdapat Sungai yang digunakan masyarakat untuk kegiatan rumah tangga dan usaha perikanan. Sebagian adapula yang memelihara ikan di keramba, kolam dan tambak. Berdasarkan data dari Dinas Kelautan dan Perikanan (DKP) Kabupaten Kutai Kartanegara (2018) produksi budidaya sektor perikanan di Kecamatan Sanga-Sanga sebesar 54,25 ton yang terbagi dari kolam sebesar 41,83 ton dan keramba sebesar 12,42 ton. Kecamatan Sanga-Sanga mampu memproduksi ikan pada tahun 2018 adalah 256,2 ton dimana jumlah konsumsinya sebesar $1.988 .200 \mathrm{~kg} / \mathrm{tahun}$, dengan jumlah penduduk di Kecamatan Sanga-Sanga sebesar 21.203 orang, maka konsumsi ikan masyarakatnya sebesar 93,76 kg/kapita/tahun, yang berada diatas kebutuhan konsumsi nasional sebesar 50 kg/kapita/tahun.

\section{Profil Responden}

Informasi tentang karakteristik pelaku usaha sangat penting, karena dapat digunakan untuk menentukan kebijakan dan program kedepannya. Arnis et al., (2019) bahwa rendahnya kinerja usaha kecil banyak disebabkan oleh faktor sumberdaya manusia. Untuk itu maka karakterisitk menyangkut pelaku usaha perlu diketahui. Adapun profil dari pelaku usaha pengolahan meliputi umur, tingkat pendidikan dan lama usaha. Kisaran umur pengolah berkisar 30-53 tahun, yang tergolong masih usia produktif. Tingkat pendidikan dari SLTA (50\%), SLTP (25\%) dan SD (25\%). Dari segi pendidikan formal, para pelaku usaha tersebut sudah cukup memadai, sehingga memudahkan dalam proses transfer teknologi. Kegiatan pendidikan non formal seperti kegiatan pelatihan dan penyuluhan pernah mengikutinya. Untuk lama usaha bervariasi dari 2 tahun sampai 5 tahun usaha tersebut telah ditekuni. Dari aspek profil tersebut, maka semua pelaku usaha ini memiliki potensi dan peluang mengembangkannya. Dari segi usia masih tergolong 
produktif, dan masih mampu menerima dan mengadopsi transfer pengetahuan dan teknologi, sehingga dalam hal ini peran pendamping (PPL) perlu diintensifkan.

\section{Profil Usaha Pengolahan Amplang}

Kegiatan usaha olahan perikanan sudah cukup lama dilakukan oleh masyarakat. Setempat. Awalnya usaha ini dilakukan secara spontanitas oleh sekelompok ibu ibu di daerah tersebut. Dari sisi lain potensi bahan baku terutama ikan bandeng yang cukup banyak dan belum dimanfaatkan, sehingga menimbulkan keinginan mereka untuk dapat mengembangkan potensi ini. Berbekal pengetahuan dan keterampilan yang dimiliki, mereka embangun usaha pengolahan perikanan. Seiring dengan berjalannya waktu, dan adanya pembinaan oleh instansi terkait (UPT Dinas Perikanan - Kelautan Kecamatan Sanga Sanga), maka dibentuklah kelompok usaha sejak tahun 2009. Penguatan kelompok menjadi bagian penting dalam upaya meningkatkan kemampuan kelompok. Sejalan dengan hasil kajian Rahayu et al., (2020) bahwa optimalisasi kinerja kelompok perlu ditingkatkan melalui kegiatan pendampingan dan pelatihan. Pembinaan melalui kelompok sangat membantu dan bisa lebih efektif. Keberadaan kelompok tersebut perlu dipertahankan dengan mengurangi kesenjangan yang ada. Haqiqiansyah et al., (2016) menyatakan bahwa dinamika kelompok perlu ditumbuh kembangkan, karena dengan dinamisnya suatu kelompok maka akan semakin kuat eksistensi kelompok tersebut.

Kegiatan usaha dijalankan menggunakan teknologi sederhana, dengan kemampuan produksi beragam, sebagian tergantung dari order/pesanan dari pembeli dan ketersediaan bahan baku ikan. Menurut Yonvitner (2014) penyiapan tempat penampungan (Bulog perikanan) saat paceklik dan perbaikan tatanan rantai pemasaran perlu diperhatikan. Setiyorini et al., (2018) dengan memperluas jaringan pemasaran dan kerjasama akan mempermudah akses bahan baku, proses penanganan bahan baku untuk proses produksi perlu dijaga kualitasnya, agar tidak menurunkan mutu dan cita rasa hasil olahan. Hasil kajian Indrastuti et al., (2019) penanganan proses produksi sebagian pelaku usaha masih belum saniter dan higienis, sehingga hasil olahan kurang baik. Hal ini perlu diperhatikan oleh pelaku usaha. Dalam proses penanganan produksi, sebagian pengolah sudah pernah mengikuti kegiatan pelatihan atau penyuluhan, sehingga sudah mampu mempertahankan mutu ikan agar tetap segar ketika akan dijadikan bahan utama pembuatan amplang.

Kapasitas produksi bervariasi dan tergantung dari orderan. Dalam satu bulan bisa dilakukan sebanyak 8-10 kali., dengan rata-rata setiap kali mengolah sebanyak 5 sampai dengan $50 \mathrm{~kg}$ per proses produksi. Pada saat tertentu bisa mengalami peningkatan permintaan. Saat peringatan hari besar nasional seperti HUT kemerdekaan dan kegiatan pameran (Expo) serta menjelang bulan puasa. Dengan semakin berkembangnya usaha tersebut, sehingga diharapkan dapat memenuhi kebutuhan pasar yang kian meningkat. 
Produk ini menjadi makanan khas daerah dan menjadi souvenir. Sejalan dengan hasil penelitian Evi et al., (2012), bahwa animo masyarakat atau permintaan akan produk olahan semakin meningkat.

Program dari Corporate Social Responbility (CSR) Pertamina di Kecamatan Sanga-Sanga berupa pelatihan membuat kemasan yang menarik serta bantuan fisik dalam bentuk kemasan plastik sangat membantu usaha tersebut. Mulyawan et al., (2019) menyatakan bahwa kemasan sangat penting dalam mempertahankan mutu produk. Selain itu pihak CSR membantu memfasilitasi untuk promosi dan pemasaran hasil, meskipun kegiatan ini tidak secara bersinambungan Keberadaan Unit Pelaksana Teknis (UPT) Kelautan dan Perikanan Kecamatan Sanga Sanga berkontribusi dalam mengembangan kegiatan usaha ini. Bantuan lainnya dari Dinas Perikanan Kota Samarinda berupa wajan, blender dan mangkok. Kelurahan Sarijaya memiliki satu kelompok usaha yang beberapa anggotanya berasal dari pengolah amplang, sehingga bantuan yang diterima dari Dinas Perikanan Kabupaten Kutai Kartanegara digunakan bersama. Bantuan tersebut adalah alat-alat produksi berupa satu set pisau, wajan, panci, sutil, baskom, basket, blender, dan serok.

Profil usaha pengolahan di Kelurahan Sarijaya tergolong usaha skala rumah tangga, penggunaan teknologi sederhana, tenaga kerja keluarga yang digunakan, pemasaran masih terbatas dan sebagian sudah memiliki izin usaha (P-IRT). Kegiatan usaha ini masih menyatu dengan tempat tinggal. Pemanfaatan teknologi yang masih belum optimal perlu diperhatikan, agar usaha ini bisa lebih baik. Indriati et al., (2017) bahwa pengenalan teknologi pengolahan kepada pelaku usaha dapat membantu meningkatkan usahanya. Identifikasi profil sangat membantu dalam menentukan kebijakan, terkait pengembangan usaha kecil dan menengah. Hasil kajian Iskandar et al., (2020) menyimpulkan bahwa diketahui karakteristik usaha akan memudahkan dalam melakukan strategi pembinaan kelompok usaha. Aspek pemasaran perlu diperhatikan, karena sebagian masih melakukan secara konvensional. Sebagian besar pendistribusian tergantung pesanan dari pelanggan. Keadaan ini tentunya dapat menghambat ketika produksi melimpah. Sehingga perlu kerjasama atau kemitraan dengan pihak lain yang dapat membantu mengatasi hal demikian.

Terdapat empat pelaku usaha pengolahan di Kelurahan Sari Jaya. Adapun profil usaha amplang yang ada di Kelurahan Sarijaya.

1. Usaha Amplang Keramat Jaya

Kegiatan usaha ini dimulai pada tahun 2014 dengan menggunakan modal dan berbekal pengetahuan seadanya. Namun seiring berjalannya waktu dan adanya program pembinaan baik dari Dinas terkait dan pihak swasta yang ada di wilayah tersebut, maka usaha tersebut mengalami perkembangan cukup lumayan. DKP Kabupaten Kutai 
Kartanegara sering mengundang dan melibatkan dalam kegiatan pameran (expo), membuat produk olahan ini cukup dikenal. Kapasitas produksi dalam satu minggu sekitar $154 \mathrm{~kg}$ dengan bahan baku ikan sebanyak $60 \mathrm{~kg}$. Bahan baku ikan diperoleh dari empang atau nelayan. Kadang kala ketersediaan bahan baku ikan tidak tersedia, sehingga dapat menyebabkan usaha terganggu bahkan berhenti sementara. Kondisi ini disadari karena produk hasil perikanan yang bersifat musiman. Upaya mengantisipasi ini, pengolah melakukan penyimpan stok bahan baku ikan dalam freezer. Kegiatan pemasaran produk amplang dilakukan secara langsung yaitu pengiriman ke berbagai pelanggan seperti Kelurahan Handil 2, Tenggarong, Kutai Barat, Balikpapan, Samarinda dan warungwarung yang ada di Kecamatan Sanga-Sanga. Bentuk varian kemasan yang dijual adalah ukuran Rp 5.000 per 50 gr, Rp. 10.000 per 100 gr, Rp. 20.000 per 200 gr, Rp. 25.000 per $250 \mathrm{gr}$ dan Rp. 100.000 per 1.000 gr. Produk sudah dikemas dengan baik dan diberi label menggunakan stiker serta sudah memiliki izin usaha (P-IRT).

\section{Usaha Amplang Kinar Sanga-Sanga}

Usaha ini telah dimulai pada tahun 2017 oleh Ibu Susilawati yang berbekal ilmu dari salah satu pengolah Muara Badak, Beliau memberanikan diri untuk menjalankan usaha ini. Beliau tidak pernah mendapatkan bantuan dari pemerintah sehingga segala jenis peralatan yang digunakan untuk kegiatan produksi dibeli dengan modal sendiri. Dalam satu minggu, mampu memproduksi sekitar $90 \mathrm{~kg}$ dengan bahan baku sebanyak 30 kg. Bahan baku diperoleh dari pedagang ikan keliling Kecamatan Sanga-Sanga. Pemasaran dilakukan secara langsung dengan mengirim ke palanggan di wilayah Kecamatan Loa Janan dan Kota Samarinda. Produk yang dijual dalam bentuk kemasan dan harga yang sama dengan pengolah lainnya.

\section{Usaha Amplang Zahara}

Usaha ini yang dimulai pada tahun 2016 dengan modal sendiri. Dengan berbagai bekal pelatihan dan penyuluhan yang diikutinya maka kegiatan ini sudah mulai berkembang. Kesulitan yang dihadapi hamper sama yaitu ketersediaan bahan baku yang kadang sulit didapat dan pemasaran yang masih terbatas. Berkat ketekunan dan bimbingan yang intensif dari penyuluh perikanan, maka hingga kini usaha tersebut sudah menunjukan hasil. Hasil produk olahan sudah menjangkau pasaran tidak hanya wilayah local, namun sudah ke luar daerah seperti Kecamatan Palaran, Kecamatan Tenggarong Samarinda, Kota Balikpapan dan Kota Samarinda. Bahkan produk tersebut sudah ke luar Kalimantan Timur pemasarannya. Kapasitas produksi dalam satu minggu bisa memproduksi sekitar sekitar $60 \mathrm{~kg}$ dengan bahan baku ikan sebanyak $30 \mathrm{~kg}$. Bahan baku diperoleh dari empang, namun terkadang diantar langsung oleh pedagang ikan. Produk yang dijual beragam bentuk kemasan mulai yang terkecil (50 gram per bungkus) sampai ukuran 1.000 gram, dengan harga sama dengan pelaku usaha lainnya. Pengolah juga 
ISSN 2354-7251 (print)

melayani pembelian dalam bentuk partai tanpa label, dan biasanya harga mendapat potongan sebesar $15-20 \%$ dari harga normal.

4. Usaha Amplang Saniah

Usaha dimulai pada tahun 2015 dengan modal sendiri, dimana pengolah masih memiliki hubungan keluarga dengan pengolah dari amplang Zahara. Bahan baku diperoleh dari empang atau dari suami yang berprofesi sebagai nelayan. Kapasitas produksi dalam satu minggu sekitar $45 \mathrm{~kg}$ dengan bahan baku ikan sebanyak $20 \mathrm{~kg}$. Kemasan yang dijual adalah ukuran dan harga hampir sama dengan pengolah lainnya. Kemasan menggunakan label stiker. Para pelaku usaha pengolahan ini sudah tergabung dalam satu kelompok usaha, namun dalam kegiatan usaha dilakukan secara masingmasing. Keberadaan kelompok untuk memudahkan tenaga penyuluh (PPL) dalam menggorganisasi kegiatannya.

\section{Analisis Kinerja Usaha Pengolahan}

Dimaksudkan untuk mengukur kelayakan dari suatu jenis usaha. Tujuan dari analisis usaha adalah untuk mengukur keuntungan, pengembalian investasi, dan titik impas suatu usaha (Effendi \& Oktariza, 2006). Untuk mengukur kelayakan dan keuntungan usaha maka analisis kinerja usaha perlu dilakukan, sehingga dapat diketahui prosfek usaha ini kedepannya. Aspek finansial menggunakan kriteria tidak terdiskonto (undiscounted), meliputi: analisis perbandingan penerimaan dan biaya $(R / C)$, analisis pendapatan dan titik impas produksi dan harga. Hasil analisis disajikan sebagai berikut:

1. Analisis Pendapatan Usaha

Pendapatan yang diperoleh dari hasil pengurangan dari total penerimaan dikurang total biaya. Dari hasil perhitungan diperoleh pendapatan rata-rata sebesar Rp. 14.076.575,5/bulan, yang berasal dari hasil rata-rata penerimaan sebesar $R p$ 25.875.000,-/bulan dikurang rata-rata total biaya yang dikeluarkan sebesar Rp. 11.798.424,5/bulan. Secara terinci dapat dilihat pada tabel berikut.

Tabel 1. Perhitungan pendapatan usaha pengolahan amplang

\begin{tabular}{clccc}
\hline No & Nama Usaha & Penerimaan (Rp/bulan) & Biaya (Rp/bulan) & Pendapatan (Rp/bulan) \\
\hline 1 & Kinar Sanga Sanga & 24.720 .000 & 10.366 .875 & 15.633 .125 \\
2 & Keramat Jaya & 45.000 .000 & 24.023 .993 & 20.976 .007 \\
3 & Saniah & 15.300 .000 & 5.776 .830 & 9.523 .170 \\
4 & Zahara & 19.200 .000 & 7.026 .000 & 12.174 .000 \\
\hline & Jumlah & 103.500 .000 & 47.193 .698 & 56.306 .302 \\
& Rata Rata & 25.875 .000 & $11.798 .424,5$ & $14.076 .575,5$ \\
\hline
\end{tabular}

Sumber: Data primer yang diolah (2019)

Dari komposisi perhitungan biaya, penggunaan bahan baku ikan mencapai sekitar $30 \%$ dari biaya yang digunakan. Seandainya mampu mengadakan bahan baku ikan (tanpa membeli) maka dapat menekan biaya yang digunakan. 
2. Analisis Imbangan Penerimaan dan Biaya

Penerimaan yang diperoleh sebesar Rp 25.875.000/bulan dan biaya yang dikeluarkan Rp 11.798.424,5/bulan, maka diperoleh nilai RCR sebesar 2,19. Nilai RCR>1 berarti usaha tersebut layak untuk dilanjutkan. Nilai RCR 2,19 memberikan arti bahwa setiap satu satuan biaya yang dikorbankan dapat memberikan kontribusi 2,19 kali dari biaya korbanan tersebut. Dengan hasil yang tren positif tersebut, maka perlu dilakukan pembinaan dan pendampingan yang lebih intensif terutama dari tenaga penyuluh lapangan, sehingga pelaku usaha ini mampu mempertahankan bahkan meningkatkan kapasitasnya lagi. Kajian Sumantri et al., (2016) menunjukan kinerja usaha pengolahan ikan yang cenderung positif, maka peran dan intensitas penyuluhan perlu ditingkatkan. Pada kegiatan usaha ini, tidak terlepas dari permasalahan yang sering dihadapi, seperti ketersediaan bahan baku ikan yang kadang sulit didapat, perluasan pangsa pasar masih belum optimal. Menyikapi kondisi ini diperlukan sinergitas dari berbagai stakeholder, baik pemerintah maupun pihak swasta untuk dapat membantu pengembangan usaha tersebut. Asiati \& Nawawi (2016) menyatakan bahwa sinergitas antara pemerintah, kelompok nelayan dan pengolah sangat penting dalam mendukung ptogram kemitraan. Program kemitraan antar UMKM dalam upaya memperluas jaringan pemasaran yang kuat perlu dilakukan (Nurhidayati \& Rikah, 2016).

3. Analisis Titik Impas

Digunakan untuk melihat keadaan dimana produksi tidak mengalami kerugian atau keuntungan. Perhitungan titik impas produksi usaha pengolahan amplang adalah 118 $\mathrm{kg} / \mathrm{bulan}$. Jika dibandingkan dengan produksi aktual sebesar $258 \mathrm{~kg} / \mathrm{bulan}$. Titik impas produksi masih berada dibawah produksi yang ada, sehingga produksi masih berada diatas ambang batas. Perhitungan titik impas harga keberada pada nilai Rp 45.597/kg, sedangkan harga jual saat ini mencapai Rp 100.000/kg. Harga jual masih berada diatas harga titik impas. Menyikapi kondisi ini maka para pelaku usaha perlu mempertahankan kapasitas produksi dan perluasan pemasaran yang lebih intensif. Terutama pada kondisi kelangkaan bahan baku ikan yang sering dialami. Kondisi ini kadang berdampak bahwa pelaku usaha terpaksa menghentikan kegiatan usaha. Maka perlu dilakukan terobosan untuk mengantisipasi keadaan ini.

\section{Kesimpulan}

Kesimpulan yang dapat dirumuskan bahwa usaha pengolahan amplang masih tergolong skala rumah tangga, teknologi sederhana, menggunakan modal sendiri, ada izin usaha dan mengandalkan tenaga kerja keluarga. Berdasarkan analisis aspek kinerja usaha menunjukan bahwa masih menguntungkan, dengan nilai RCR sebesar 2,19 dan Nilai titik impas produksi $118 \mathrm{~kg} / \mathrm{bulan}$ dan titik impas harga sebesar Rp 45.597/kg. 
Adapun saran yang perlu ditindak lanjuti adanya pendampingan oleh pihak terkait (PPL) lebih intensif sehingga dapat meningkatkan kualitas produksi dan program kemitraan untuk perluasan segmentasi pasar.

\section{Daftar Pustaka}

Arnis, N., Burhanuddin, B., \& Priyatna, W. B. (2019). Karakteristik Pelaku Usaha Ikan Asin di Muara Angke. Journal of Food System \& Agribusiness, 2(2), 107-119. https://doi.org/10.25181/jofsa.v2i2.1117

Asiati, D., \& Nawawi, N. (2016). Kemitraan Di Sektor Perikanan Tangkap: Strategi Untuk Kelangsungan Usaha Dan Pekerjaan. Jurnal Kependudukan Indonesia, 11(2), 103. https://doi.org/10.14203/jki.v11i2.204

Badan Pusat Statistik Kabupaten Kutai Kartanegara. (2018). Kabupaten Kutai Kartanegara Dalam Angka tahun 2018. Tenggarong

Dinas Kelautan dan Perikanan Kutai Kartanegara. (2018). Laporan Statistik Kelautan dan Perikanan Kutai Kartanegara

Effendi, I., \& Oktariza, W. (2006). Manajemen Agribisnis Perikanan. Jakarta: Penebar Swadaya.

Evi, S. U., Mahreda, E. S., \& Dekayanti, T. (2012). Analisis Usaha Pengolahan Amplang Ikan Pipih (Notopterus chilata) Skala Rumah Tangga di Kota Palangka Raya Provinsi Kalimantan Tengah. Fish Scientiae, 2(3), 64-74.

Hadiwiyoto, S. (1993). Teknologi Pengolahan Hasil Perikanan. Yogyakarta: Liberty.

Haqiqiansyah, G., Fidhiani, D. D., \& Sulistianto, E. (2016). Analisis Dinamika Kelompok Tani Nelayan Di Pesisir Kota Bontang. Agriekonomika, 5(1), 31. https://doi.org/10.21107/agriekonomika.v5i1.1288

Haqiqiansyah, G., \& Sugiharto, E. (2018). Coastal women empowerment in improving enterprise of fish product processing in Sanga-Sanga Districts. IOP Conference Series: Earth and Environmental Science, 144(1). https://doi.org/10.1088/1755$1315 / 144 / 1 / 012054$

Indrastuti, N. A., Wulandari, N., \& Palupi, N. S. (2019). Profil Pengolahan Ikan Asin di Wilayah Pengolahan Hasil Perikanan Tradisional (PHPT) Muara Angke. JPHPI, 22(2), 218-228.

Indriati, S., Masúd, F., \& Todingbua, A. (2017). Pengolahan Produk Hasil Perikanan Di Kelurahan Pincengpute, Kabupaten Wajo. Seminar Nasional Hasil Pengabdian Kepada Masyarakat (SNPM) 2017, 2017, 140-144. Retrieved from http://jurnal.poliupg.ac.id/index.php/snp2m/article/download/1303/1201

Iskandar, Y., Zulbainarni, N., \& Jahroh, S. (2020). Pengaruh Karakteristik Usaha dan Wirausaha Terhadap Kinerja UMKM Industri Pengolahan Perikanan di Kabupaten Sukabumi. Jurnal Riset Ekonomi Manajemen (REKOMEN), 4(1), 1-12. https://doi.org/10.31002/rn.v4i1.2205

Mulyawan, I. B., Handayani, B. R., Dipokusumo, B., Werdiningsih, W., \& Siska, A. I. (2019). Pengaruh Teknik Pengemasan dan Jenis Kemasan Terhadap Mutu dan Daya Simpan Ikan Pindang Bumbu Kuning. Jurnal Pengolahan Hasil Perikanan Indonesia, 22(3), 464-475. https://doi.org/10.17844/jphpi.v22i3.28926 
Nugroho, M. (2015). Pemberdayaan Masyarakat Nelayan Di Kabupaten Pasuruan: Kajian Pengembangan Model Pemberdayaan Sumberdaya Manusia Di Wilayah Pesisir Pantai. Teknologi Pangan: Media Informasi Dan Komunikasi Ilmiah Teknologi Pertanian, 6(1). https://doi.org/10.35891/tp.v6i1.464

Nurhidayati, A., \& Rikah. (2016). Strategi Kemitraan UMK Pengolah Ikan di Kabupaten Rembang. Buletin Bisnis \& Manajemen, 2(1), 1-8.

Rahayu, W., Marwanti, S., Agustono, A., Ferichani, M., Khairiyakh, R., \& Nurhidayati, I. (2020). Peningkatan Kinerja Kelompok Usaha Pengolahan Ikan Air Tawar di Kabupaten Sleman. AgriHealth: Journal of Agri-Food, Nutrition and Public Health, 1(2), 89. https://doi.org/10.20961/agrihealth.v1i2.44389

Setiyorini, E. S., Noorachmat, B. P., \& Syamsun, M. (2018). Strategi Pemasaran Produk Olahan Hasil Perikanan pada UMKM Cindy Group. MANAJEMEN IKM: Jurnal Manajemen Pengembangan Industri Kecil Menengah, 13(1), 19. https://doi.org/10.29244/mikm.13.1.19-28

Setyaningrum, A., \& Hartanto, B. W. (2020). Peningkatan Kapasitas Istri Nelayan dalam Pengolahan Hasil Perikanan di Dusun Kuwaru, Kecamatan Srandakan, Kabupaten Bantul. Jurnal Panrita Abdi, 4(2), 184-194. Retrieved from http://journal.unhas.ac.id/index.php/panritaabdi

Soekartawi. (1990). Teori Ekonomi Produksi. Jakarta: Rajawali Press.

Sumantri, B., Purwoko, A., \& Sriyoto, . (2016). Analisis Kinerja Usaha Pembuatan Ikan Kering $\mathrm{Di}$ Kota Bengkulu. Jurnal AGRISEP, 15(1), 15-26. https://doi.org/10.31186/jagrisep.15.1.15-26

Yonvitner, Y. (2014). Bahan Baku: Urat Nadi Industri Pengolahan Perikanan Mikro Kecil Dan Menengah. RISALAH KEBIJAKAN PERTANIAN DAN LINGKUNGAN: Rumusan Kajian Strategis Bidang Pertanian Dan Lingkungan, 1(3), 187-191. https://doi.org/10.20957/jkebijakan.v1i3.10296

Yudaswara, R. A., Rizal, A., Pratama, R. I., \& Suryana, A. A. H. (2018). Analisis Kelayakan Usaha Produk Olahan Berbahan Baku Ikan Nila (Oreochromis niloticus) (Studi Kasus di CV Sakana Indo Prima Kota Depok). Jurnal Perikanan Dan Kelautan, 9(1), 104-111. 